Andreas Fülberth

\title{
LEIPZIG UNIVERSITY AT THE TIME OF JOHANN WILHELM KRAUSE AND ITS MODERNISATION DURING THE 19 ${ }^{\text {TH }}$ CENTURY
}

Although the Saxon city of Leipzig can hardly be said to be, or to have been, closely connected to the Baltic Sea Region, cultural ties between this city and the territories of Estonia, Latvia and Lithuania are more numerous than one might expect. Reflecting upon these ties, Germans tend to mention their famous composer Richard Wagner (1813-1883), who was born in Leipzig and whose first professional positions included that of conductor at the Riga Theatre from 1837 to 1839. Latvians may associate Duke Jacob Kettler, who reigned in Courland from 1642 to 1682, or even Kārlis Ulmanis (1877-1942), President of Latvia during the second half of the 1930s, with such kinds of Balto-Saxon relationships: both of these men have been students at Leipzig University - the former for a short time in the early 1620s, the latter from 1903 to 1905, when he attended lectures on agriculture. Lithuanians will be inclined to add the name of their most prominent artist Mikalojus Konstantinas Čiurlionis (18751911), who perfected his musical skills at the Leipzig Conservatory. Čiurlionis left the city about one year before Ulmanis arrived. The case of Johann Wilhelm Krause (1757-1828), whose architectural works enrich the city of Tartu, Estonia, differs from those of Kettler,

DOI: https://doi.org/10.12697/BJAH.2018.15.10 
Ulmanis and Čiurlionis in regard to the influence that Leipzig as a whole exerted on his subsequent career and creativity (rather than the knowledge he gained at Leipzig University).

Krause, who became a student at Leipzig University in 1778, would never have come away with as many of the pleasant impressions of the city as he did, if he had come to the city a few years earlier or several years later, because of the number of new parks that were established in the city during this interval of time. Based on a resolution passed by the authorities to get rid of the town walls as soon as possible, public gardens and recreation areas were emerging all around the town under Krause's very eyes. In the field of architecture, a profession he strongly desired to acquire although he had reconciled himself to studying theology instead, he would have to wait another 15 years to be truly impressed by something he saw in Leipzig. This fascinating experience resulted from the changes that were made inside St Nicholas Church between 1784 and 1797 - some years after Krause had discontinued his theology studies in 1781. These changes were carried out by Carl Friedrich Dauthe (17461816), who had been appointed to be the municipal Baudirector (literally: supervisor of building activities) in 1780, and by Adam Friedrich Oeser (1717-1799), who was responsible for the paintings. Dauthe succeeded in designing an innovative early neoclassical interior mixed with an essentially Gothic Revival spirit, flooded with light and adorned with characteristic palm leaf capitals, something that had not existed in any parish church in Germany before. ${ }^{1}$ It can easily be seen that Krause's later vision of how Tartu Cathedral could look after having risen from the ruins testified to a longing to create a reborn cathedral structure for Tartu that resembled St Nicholas Church in Leipzig (especially as far as the interiors were concerned).

As fate would have it, St Nicholas Church is the only one of Dauthe's numerous works that has not fallen victim to destruction. Another interesting case is Löhr's House and Löhr's Garden (Löhrs Haus and Löhrs Garten in German), for which all the designs were most likely made by Dauthe, although his authorship could never be proved. ${ }^{2}$ Löhr's House,

1 Cf. Juhan Maiste, 'Ülikool pargis', Johann Wilhelm Krause 1757-1828, kataloog 3: linnaehitajana Tartus $=$ Als Stadtbauer in Tartu, ed. by Juhan Maiste, Anu Ormisson-Lahe (Tartu, Tallinn: Tartu Ülikool, Eesti Keele Sihtasutus, 2011), 13-55, here 42.

2 Christian Forster, 'Carl Friedrich Dauthe: Löhrs Garten und Löhrs Haus in Leipzig. Ein früher Landschaftsgarten und ein Palais im Zopfstil', Leipzig um 1800. Beiträge zur Sozialund Kulturgeschichte, ed. by Thomas Topfstedt, Hartmut Zwahr (Beucha: Sax-Verlag, 1998), 143-162, here 144. 
built starting in 1777 for a local banker of the same name, resembled the palace in Wörlitz, a well-known example of German Neoclassicism, and was situated in close proximity to the north-western corner of the town centre. Right behind it, the public could enter a fan-shaped garden that reached as far as the small Parthe River and was planted with various species of trees chosen by Löhr starting in 1770. A garden project of that kind may be defined as typical of the Age of Enlightenment insofar as, for a wealthy merchant or banker such as Löhr, it was combined with a suggestion of altruism. ${ }^{3}$ However, this attribution was not linked to the style of the garden, but would also have applied to Apel's Garden (Apels Garten in German) west of the town centre; to the Large Bose Garden (Grossbosischer Garten) southeast of it; or even to Barthel's Garden (Barthels Garten), a sort of predecessor of Löhr's Garden: All of these recreation areas formed an ensemble of baroque gardens which were open to the citizens who liked to use them for promenades. The uniqueness of Löhr's Garden was comprised of an unmistakable idealisation of the principles of English landscape gardening - even if only the eastern half, which surrounded an English bridge leading to a small island in a pond, actually observed these principles, whereas more conservative elements (such as a main axis) dominated the western half.

It seems reasonable to go into more detail about this project here because Löhr was the first non-aristocratic German to establish an English garden near a town; and the green landscaping typical of Leipzig at the end of the $18^{\text {th }}$ century cannot be explained only by referencing the parks that Dauthe designed for the grounds of former fortifications between the Halle Gate (Hallesches Tor in German) and Grimma Gate (Grimmaisches Tor). Furthermore, only one generation had the privilege of enjoying Löhr's Garden in its original beauty, and Johann Wilhelm Krause was among the lucky ones who even witnessed the process of the garden being planted, which must have been of considerable interest to him. If, by contrast, his descendants had visited Leipzig at a similar age, they would only have seen the disastrous effects of the Battle of the Nations in October 1813, from which Löhr's Garden never recovered. ${ }^{4}$

3 Forster, 'Carl Friedrich Dauthe: Löhrs Garten und Löhrs Haus in Leipzig. Ein früher Landschaftsgarten und ein Palais im Zopfstil', 145.

4 Finally, at the end of the century, the garden ground was divided into small parcels of land to be filled with dwelling-houses, while Löhr's House changed its appearance and became a hotel. 
After so many preliminary remarks about other noteworthy places in the town, attention should now be turned to the university itself. With its 30,000 inhabitants at the end of the $18^{\text {th }}$ century, ${ }^{5}$ Leipzig did not have much in common with the smaller university towns (such as Jena) in which the presence of students was much more visible. ${ }^{6}$ Sometimes Leipzig was even said to be a town with a universitas pauperum, because the intensity of its economic life always attracted students who were forced to earn their own livings. Such necessities did not concern all the local students, but had a much greater impact here than, for example, in Göttingen, where students of noble origin were comparatively easy to find. The Leipzig University itself could do little for the welfare of its students because its own circumstances were quite precarious. Traditionally, the university was divided into various colleges, each of which had to finance itself independently. Therefore, many of the rooms in the university's buildings were used as stores or flats by companies or individuals (usually professors or students) who paid rent to the college. The difficult financial situation of some of the colleges continued even after 1830, when far-reaching reforms, which had been planned since 1806, were fortunately enacted and resulting in more funding by the state. The situation of the so-called Great College is an example of how poorly the need for lecture-rooms was satisfied by the colleges at Leipzig University before that reform. At the Great College, the most important auditorium of the Faculty of Medicine, the most important auditorium of the Faculty of Philosophy and the room reserved for the election of new rectors were all located on the adjacent floors of the same modest building behind a courtyard. ${ }^{7}$ Behind the auditoriums, countless generations of students looked out on the medieval town

5 To be more exact, the census data collected in 1789 resulted in a total number of 32,144 inhabitants. Otto Künnemann, Martina Güldemann, Geschichte der Stadt Leipzig (GudensbergGleichen: Wartberg, 2014), 63.

6 Kathrin Löffler, 'Leipziger Studentenleben im 18. Jahrhundert', Leipziger Stadtgeschichte. Jahrbuch 2010, ed. by Markus Cottin, Detlef Döring, Cathrin Friedrich (Beucha, Markkleeberg: Sax-Verlag, 2011), 189-217, here 194.

7 Birgit Hartung, 'Die Bauten der Universität Leipzig vom Dreissigjährigen Krieg bis 1830', Geschichte der Leipziger Universitätsbauten im urbanen Kontext, ed. by Michaela Marek, Thomas Topfstedt. Geschichte der Universität Leipzig 1409-2009, Bd. 5 (Leipzig: Leipziger Universitätsverlag, 2009), 51-75, here 64. 
wall casting its shadow. Even the last of these generations had to cross the old dark courtyard while the town wall was being demolished and yet it is evident how essential this demolition was for the future advancement of learning and research at Leipzig University.

The defensive walls and towers had turned out to be nearly useless during the Seven Years' War (1756-1763), which meant that the need to demolish them was understood at a remarkably early stage in history. ${ }^{8}$ After some years, many of the buildings that had been hidden by the town wall for hundreds of years were exposed. Suddenly they were more visible from completely new points of view. One of these buildings was the former Dominican monastery, which, along its St Paul's Church was built around 1230 on the eastern edge of the medieval town. In 1543, only four years after the Reformation had been adopted throughout the Duchy of Saxony, the monastery became the property of the university, which had made a claim for it. Separated from three of the colleges only by a street called Grimmaische Strasse (which connected Leipzig with its suburbs in the east and the neighbouring town of Grimma), the former monastery was predestined to develop into a kind of centre for the university.

When Krause first arrived in Leipzig in 1778, an expansion of the so-called Petrinum or Collegium Juridicum near the southwestern corner of the historical inner town was of benefit to those who attended the lectures on jurisprudence, if not to anyone else. Krause himself found lodgings a few hundred meters southeast of the inner town. He probably observed that the students who were familiar with the town would spend their daily hours of leisure in the surrounding greenery. In the afternoons, many of them would take rides in the horse-drawn carriages that were available for such purposes in front of Grimma Gate. ${ }^{9}$ However some of Krause's favourite places were outside the inner town but within easy walking distance. As we know from his diaries, he admired the parks between the old

8 This was quite an early beginning in comparison with, for instance, Hamburg, Vienna or Cologne, where the demolition of the walls started in 1820,1857 and 1875 respectively.

9 Löffler, 'Leipziger Studentenleben im 18. Jahrhundert', 208. 
southern and eastern town gates for the busts and monuments of renowned poets and philosophers located there. ${ }^{10}$

Krause's time as a student ended in 1781, which was quite a memorable year in the cultural life of Leipzig. While Leipzig had formed a professional orchestra at the initiative of the citizenry earlier than any other German town, it still lacked a proper concert hall. However, in 1781, a hall that the orchestra and the local music audience had been deserving of for nearly half a century was finally built. It was designed by Carl Friedrich Dauthe in the upper part of a historical structure in the Old Town - the so-called Gewandhaus (literally: Cloth Hall). And as a result, the Gewandhausorchester, derived from the name of its first home, became the nickname for the orchestra. Later the name Gewandhaus turned out to be so popular that it was transferred to the new building for the increasingly famous orchestra in the late $19^{\text {th }}$, and again in the late $20^{\text {th }}$, century.

We do not know for certain whether Krause paid any particular attention to the aforementioned measures undertaken for the orchestra in 1780-1781. However, it would be logical to assume that there must have been reasons why his most brilliant idea for Tartu at the beginning of the $19^{\text {th }}$ century - the idea to transform the chancel of a ruined medieval cathedral into a library - seemed so convincing in his own mind. Actually, one reason may have been the conversion of the old cloth hall into a concert hall, which Krause had witnessed in Leipzig. Assuming this is true, we must also admit that cities such as St Petersburg (where Krause spent some time in 1791) left a much deeper impression on him and that their influence on his later designs for Tartu should not be underestimated. ${ }^{11}$ Nevertheless it seems obvious that Krause was pragmatic enough to know that the University of Tartu could not be modelled primarily after St Petersburg.

Krause's last visit to Leipzig in 1796 - a stopover on his way to Switzerland where he would join his friend Carl Grass (1767-1814) provided an opportunity for him to see various buildings that had been altered since his time as a student in the town. For example, he

10 For quotations from the respective volume of his diaries, in which Leipzig and, among other details, the monument to Christian Fürchtegott Gellert (1715-1769) is being touched, see Juhan Maiste, Kadi Polli, Mariann Raisma, Alma Mater Tartuensis: Tartu ülikool ja tema arhitekt Johann Wilhelm Krause (Die Universität Tartu und ihr Architekt Johann Wilhelm Krause I Tartu University and its Architect Johann Wilhelm Krause) (Tallinn: Eesti Keele Sihtasutus, 2003), 59-67.

11 Maiste, Polli, Raisma, Alma Mater Tartuensis, 130-132. 
undoubtedly noticed the observatory that had been placed (based on Dauthe's design) on the tower of the so-called Pleissenburg (literally, 'castle near the river named Pleisse') some years before. ${ }^{12}$ Krause knew the Pleissenburg building quite well since the academy of arts ${ }^{13}$ had been installed in one of its wings in 1765, and was still located there at that crucially disappointing moment in 1779 when he tried in vain to be accepted at the academy.

From 1804 to 1842, another wing of that spacious former castle was occupied by the institute of chemistry which had been established at Leipzig University in $1710 .{ }^{14}$ However, the building not only united all the astronomers, artists and chemists under one roof, but major parts of it still served as barracks. The long history of the Pleissenburg structure reached its end in 1895 when it was bought by the municipality with the intention of replacing it with a new town hall. This did not cause any problems for the observatory because, in 1861, new facilities for the local astronomers had been installed in the so-called Johannistal (literally: St John's Valley) - a place less than one kilometre east of the Old Town. ${ }^{15}$ For the chemists, the provision of more comfortable accommodations began in 1842 with the completion of the so-called Fridericianum near the southern end of the former monastery. The demolition of the Pleissenburg finally resulted in only the lower parts of its tower surviving. They were used as a base for a new tower, and thanks to this tower the town hall erected in 1899-1905 bears a resemblance to its predecessor (fulfilling the wishes of many citizens).

Surely the observatory's position on top of the Pleissenburg could not have inspired Krause to place the observatory of the University of Tartu on top of a hill that once had been crowned by a medieval bishop's castle and been characterised by fortification walls on its slopes. The conditions

12 Hans-Joachim Ilgauds, Gisela Münzel, Die Leipziger Universitätssternwarten auf der Pleissenburg und im Johannistal. Astronomische Schulen von Weltruf (Beucha: Sax-Verlag, 1995), 6.

13 Maiste, Polli, Raisma, Alma Mater Tartuensis, 60. The director of this academy was Adam Friedrich Oeser, whose posthumous fame has become inseparable from the fact that he taught the art of drawing to Goethe. Krause was filled with admiration for a marble urn designed by Oeser for the tomb of the Prussian field marshal James Keith (1696-1798) in Hochkirch in Upper Lusatia.

14 Hartung, 'Die Bauten der Universität Leipzig vom Dreissigjährigen Krieg bis 1830', 68-69.

15 Ilgauds, Münzel, Die Leipziger Universitätssternwarten, 18. 
in Tartu, a town with hills, are very different from those in Leipzig, a town located on a flat area. However, Krause's ability to combine various parts into a whole was astonishing, and from time to time, the background of one's inspiration can be rather abstract. Therefore, it seems worth describing what he could have seen with his own eyes during his stay in 1796 if he walked to the southeast corner of the town. At that time, the first public school in Leipzig was under construction in quite an extraordinary place - on top of the so-called Moritzbastei - a bastion built in the 1550s which had seemed worthy of partial preservation while the rest of the former fortification system had been demolished. Like so many other buildings in Leipzig, one wing of the school, which was already completed as early as 1804, was designed by Dauthe.

In some respect Dauthe's role in designing the framework of urban development in Leipzig may be considered comparable to the role played by Krause in Tartu some years later. The only argument against such a comparison would be that the same comparison could also be made related to Albert Geutebrück (1801-1868), the most important member of the next generation of architects in Leipzig. ${ }^{16}$ Geutebrück was charged with coming up with the architectural concept for a central university building adjacent to St Paul's Church, on the site of the eastern wing of the former monastery that was demolished in $1829 .{ }^{17}$ In 1831 the cornerstone of its successor could be laid: a building mirroring the dignity of science that as one of the earliest German university buildings took shape in a purely classical style with a strictly symmetrical facade. Geutebrück's decisions regarding the arrangement of the interior and certain details of the facade were based on the advice of Karl Friedrich Schinkel (1781-1841). ${ }^{18}$

\footnotetext{
16 To be accurate, it should be mentioned that Geutebrück was employed as an official university architect, whereas in Dauthe's lifetime the actual holders of that office had been Johann Gottfried Langen (from 1763 to 1788) and then Carl August Benjamin Siegel. Langen and Siegel had not received any regular salary because there had been an agreement to consult them only on occasion. Cf. Hartung, 'Die Bauten der Universität Leipzig vom Dreissigjährigen Krieg bis 1830', 66.

17 Cf. ibidem, 72.

18 For details about the famous Prussian architect's criticism of Geutebrück's initial designs see Michaela Marek, 'Rentabilität - Funktionalität - Repräsentation. Innerstädtische Bauaktivitäten der Universität Leipzig im 19. Jahrhundert', Geschichte der Leipziger Universitätsbauten im urbanen Kontext, ed. by Michaela Marek, Thomas Topfstedt. Geschichte der Universität Leipzig 1409-2009, 5 (Leipzig: Leipziger Universitätsverlag, 2009), 133-249, here 140-144.
} 
For financial reasons, the building was declared to be a monument to the Saxon King Friedrich August I, who had died in 1827. This designation paved the way for expedients to urge the estates of the kingdom to cover some of the expenses related to the project. ${ }^{19}$

Generally, the front and rear of the old monastery lot had been inverted when this new university building was completed in 1836. The fact that up to then the western side had been regarded as front of the lot can be deduced from the very name Vorderpaulinum, which was applied to a university building right near the so-called Neumarkt (literally: New Market). The Vorderpaulinum underwent its last general reconstruction between 1797 and 1805 and it was not until 1894 that the university could afford to replace it with a new structure.

Meanwhile, the process of turning the former rear into the front reached its decisive phase when a new square began to appear east of the new central university building inaugurated in 1836. While the western flank of this Augustusplatz (named after the contemporary King of Saxony) was formed by the university building and St Paul's Church, the lot on its southern side was chosen for an art museum..$^{20}$ The latter was counterbalanced on the northern side by a new theatre ${ }^{21}$. And the new buildings planned for the eastern side included an eye-catching post office, which was designed to offset the university structures.

It was even thought that St Paul's Church needed a more solemn facade to help emphasise the intended symbolic quality of Augustusplatz as one of the most splendid squares in Saxony. ${ }^{22}$ Geutebrück, who first and foremost adhered to the concepts of Neoclassicism, recognised that a solution based on the Gothic Revival style had to be found for the gable of the church. After his proposals had materialised, this Gothic Revival gable looked rather noble and

19 Marek, 'Rentabilität - Funktionalität - Repräsentation. Innerstädtische Bauaktivitäten der Universität Leipzig im 19. Jahrhundert', 139.

20 Opened in 1848 and originally called 'Bildermuseum', this building was in ruins since World War II and finally demolished in 1962.

21 Opened in 1858, this structure was devastated by war in 1943 and demolished only seven years later in order to use its ground for a new opera building. 'New theatre' (Neues Theater in German) was in fact its official name because another theatre - called 'old theatre' (Altes Theater) since then - had already been built during the 1760 s on the very first ground which had been gained by filling up former defensive trenches north to the inner town.

22 Hartmut Mai, 'Die Universitätskirche St. Pauli', Geschichte der Leipziger Universitätsbauten im urbanen Kontext, ed. by Michaela Marek, Thomas Topfstedt. Geschichte der Universität Leipzig 1409-2009, 5 (Leipzig: Leipziger Universitätsverlag, 2009), 77-132, here 118-119. 
sombre and actually harmonised with the Neoclassical Augusteum. However, the problem of bringing these two buildings in harmony with each other had to be dealt with again at the end of the century, when the Augusteum was covered with a florid Renaissance Revival facade, while the church gable was allowed to maintain its Gothic Revival style but could not escape becoming richly ornamented.

In principle, the decision to designate the Augusteum opened in 1836 as a memorial to the late king caused difficulties. Many experts felt that this designation meant that the building should not be further altered. However, ultimately the supporters of a new facade won out and the magnificence of the structure resolved most of the traditional style differences between a university building and a palace. Schinkel had once stressed this distinction by recommending an entrance that corresponded to only one of the 25 window axes of the facade. In contrast, the new facade, which was designed by Arwed Rossbach (1844-1902), included a porch that was as wide as three axes. The former portal was reconstructed in front of a nearby open space between the university buildings as a small sign of respect for Schinkel.

The additional rooms that accompanied the completion of the Augusteum reduced many of the inconveniences related to studying at Leipzig University. However, the library did not benefit at all from this new building. And a significant improvement in the spatial situation of the university was not achieved until the university library no longer had to share a building with other institutions and was given a structure of its own. The rectangular lot on which the new library could open its doors in October 1891 was situated about 300 meters southwest of the medieval town, where its future neighbours were a large court structure to the east, ${ }^{23}$ the conservatory to the west, and the academy of arts ${ }^{24}$ to the north. The famous Leipzig concert hall, now housed in a completely new building, but

23 Called Reichsgerichtsgebäude when it was inaugurated in 1895, this building was changed into an art museum after World War II. About one decade after the reunification of the GDR with the Federal Republic of Germany, however, its function as a kind of 'Palace of Justice' has been renewed by housing the Federal Administrative Court of Germany in it.

24 Formally this was still the academy once led by Oeser in the Pleissenburg building. 
still called Gewandhaus, was just a few meters to the south. Since the concert hall did not extend as far west and east as the library did, the latter's mighty Renaissance Revival sandstone facade was visible from at least two excellent points of view. This was probably the main reason why Arwed Rossbach, the architect who won the competition for the library building in 1885, accentuated the corner sections of the facade so as to make them appear nearly as striking as the central section above the entrance.

During World War II about 65 percent of the building was heavily damaged and only one third remained in use until the end of the GDR. In 1992, an ambitious restoration project would be started to restore much of the building's original appearance, although two former courtyards had to be roofed over in order to increase the number of seats available for readers.

Interestingly, the site southwest of the Old Town had not been the only one under discussion in the 1880s when the best possible lot was being sought. Ludolf Krehl (1825-1901), head of the library at that time, along with other influential persons would have preferred demolishing the aforementioned school structure on Moritzbastei and building the library there. Summarising the advantages of that alternative, they had pointed out that nowhere else would the planned library have been so close to the main building of the university and to the inner city, and yet not entirely surrounded by neighbouring buildings. ${ }^{25}$ Regarding the latter consideration, the danger of fire had played an important part, even if aesthetic aspects may have appeared equally significant.

In 1943 a bombardment of the city was launched, and during those horrific hours, fire threatened the buildings throughout the city centre, no matter where they had been placed half a century before. After this episode of World War II, which was the worst in the entire region, only the bare shells of buildings such as the Augusteum were left standing. However, restoring them would have been technically possible.

The $30^{\text {th }}$ of May 1968 can be seen as a fateful date, the memory of which seems even more depressing. St Paul's Church was dynamited on that day because all the attempts to prevent Walter Ulbricht

25 Marek, 'Rentabilität - Funktionalität - Repräsentation. Innerstädtische Bauaktivitäten der Universität Leipzig im 19. Jahrhundert', 72. 
(1893-1973), the leader of the GDR, from having his sacrilegious orders carried out had failed. And this despite the fact that this masterpiece of Gothic architecture had not been affected by World War II. Therefore, there could only be one motive for this barbaric act - preserving St Paul's Church would have been in contradiction with Ulbricht's visions for a 'Socialist' square. Needless to say, Geutebrück's and Rossbach's Augusteum was also slated for demolition, because the prevailing architectural fashion of the time called for structures built in a functionalist spirit.

In 1972, a nearby skyscraper, also built for the university, began to dominate the skyline of Leipzig's Old Town. After the demise of the GDR, Leipzig University did not want to retain possession of this outstanding piece of architecture, which was also one of the tallest buildings in GDR, because too much money was needed for the upkeep. However, the amounts that have been spent for the new modernist Augusteum, that replaced the GDR-style structure, were by far larger. The new Augusteum has been merged with the Paulinum, a combination of church and assembly hall, which is intended to be a substitute for the medieval church, which was lost in 1968, by imitating its architecture. Finally inaugurated in December 2017, the Paulinum manifests the landmark character that university buildings have shown in the cityscape for at least two centuries and it may guarantee the preservation of this character in the future.

Andreas Fülberth: Leipzig University at the Time of Johann Wilhelm Krause and Its Modernisation during the $19^{\text {th }}$ Century KEYWORDS: UNIVERSITY OF LEIPZIG; UNIVERSITY ENSEMBLE; ARCHITECTURE; Enlightenment; Johann Wilhelm Krause; history of Leipzig; Johann Carl Friedrich Dauthe

Andreas Fülberth has been working as a Research Associate at the Centre for the History and Culture of East Central Europe at the University of Leipzig (GWZO) and in 2017 and 2018 at the Leibniz Institute for the History and Culture of Eastern Europe in Leipzig. Fülberth received a PhD degree in the History of Eastern Europe 
in Münster in 2005. From 2004 until 2014 he was a lecturer at the University of Kiel. His main fields of study are connected to urban history, especially the history of Riga in this context. In 2014, his book Riga. Kleine Geschichte der Stadt was published, in which the political and architectural development of that city is portrayed from the $12^{\text {th }}$ century to the present. In process is a volume (based on a conference held in 2016) about the history of heritage protection in Estonia, Latvia and Lithuania (especially under Soviet rule). 
